Article

\title{
Quantitative Estimation of Soil-Ground Water Storage Utilization during the Crop Growing Season in Arid Regions with Shallow Water Table Depth
}

\author{
Tianxing Zhao ${ }^{1} \mathbb{D}$, Yan Zhu ${ }^{1, *}$, Jingwei $\mathrm{Wu}^{1}{ }^{1}$, Ming $\mathrm{Ye}^{2}$, Wei Mao ${ }^{1}$ and Jinzhong Yang ${ }^{1}$ \\ 1 State Key Laboratory of Water Resources and Hydropower Engineering Science, Wuhan University, \\ Wuhan 430072, China; zhaotianxing@whu.edu.cn (T.Z.); jingwei.wu@whu.edu.cn (J.W.); \\ weimao@whu.edu.cn (W.M.); jzyang126@126.com (J.Y.) \\ 2 Department of Earth, Ocean, and Atmospheric Science, Florida State University, Tallahassee, FL 32306, USA; \\ mye@fsu.edu \\ * Correspondence: zyan0701@163.com; Tel.: +86-27-6877-5432
}

Received: 23 October 2020; Accepted: 27 November 2020; Published: 29 November 2020

\begin{abstract}
Water storage in unsaturated and saturated zones during the crop non-growing season is one of the important supplementary water resources to meet crop water requirements in arid areas with shallow water table depth. It is necessary to analyze utilization of the soil-ground water storage during the crop growing season and its attribution to irrigation during the non-growing season. To facilitate the analysis, a new method based on measurements of soil moisture content and water table depth is developed. The measurements used in this study include (1) 15-year data of soil moisture content within a depth of $1 \mathrm{~m}$ from the land surface and water table depth measured in Jiefangzha, including its four subareas and (2) 4-year data of the same kind in Yonglian, located in arid northern China. The soil-ground water storage utilization is calculated as the difference of water storage between the beginning and end of the crop growing season in the whole computational soil profile. The results of average soil-ground water storage utilization in Jiefangzha and its four subareas and Yonglian are $121 \mathrm{~mm}, 126 \mathrm{~mm}, 113 \mathrm{~mm}, 124 \mathrm{~mm}, 185 \mathrm{~mm}$ and $117 \mathrm{~mm}$, and the corresponding average utilization efficiencies in the non-growing season are $32.2 \%, 32.5 \%, 31.5 \%, 31.6 \%, 57.3 \%$ and $47.6 \%$, respectively. Further, the water table fluctuation method was used to estimate the variation in water storage. The coefficients of soil-ground water storage utilization, soil-ground water storage utilization below $1 \mathrm{~m}$ soil depth and ground water utilization are defined, and their average values are $0.271,0.111$ and 0.026 in Jiefangzha, respectively. Then, the contribution of soil-ground water storage utilization to actual evapotranspiration is evaluated, which are over $23.5 \%$ in Jiefangzha and Yonglian. These results indicate that the soil-ground water storage plays an important role in the ecological environment in arid areas with shallow water table depth.
\end{abstract}

Keywords: soil-ground water storage utilization; coefficient of soil-ground water storage utilization; ground water utilization; shallow water table depth; non-growing season irrigation

\section{Introduction}

Agricultural irrigation has consumed the largest amount of fresh water in most countries over recent decades due to the rapid increase in agricultural areas [1], which may aggravate water resources scarcity and lead to a challenge for socio-economic development [2], especially in arid regions [3]. Water consumed by plants is not only supplied by irrigation water, but also by water storage in the unsaturated and saturated zones in arid areas with shallow water table depth $[4,5]$. The irrigation or precipitation water during the non-growing season can be stored as soil water and ground water, which 
can be utilized by crops during the crop growing season. Therefore, it is important to quantitatively analyze the utilization of the soil-ground water storage during the crop growing season. This paper focuses on quantitatively estimating soil-ground water storage usage during the crop growing season and analyzing its impact factors.

The study site of this research is the Hetao Irrigation District located in the upper reaches of the Yellow River, which is one of the three largest irrigation districts in China. Autumn irrigation after crop harvest happens in late autumn to leach salt and to reserve soil water and ground water for the next crop growing season [6,7]. The autumn irrigation consumes approximately one-third of the annual amount of water diverted from the Yellow river [8]. There are plans to decrease the amount of autumn irrigation water, due to the shortage of surface water resources of the Yellow river [9]. However, considering that part of autumn irrigation water is used by crops during the crop growing season, decreasing autumn irrigation water may result in water shortage [10]. Thus, estimating the soil-ground water storage utilization in the autumn irrigation (non-growing season) is of significant importance for adjusting a suitable irrigation quota during the crop growing season and maintaining crop production in this area. What is more, analyzing the influence mechanism of the impact factors (including the autumn irrigation scheme and planting structure) on soil-ground water storage utilization is useful for water management in arid areas with shallow water table depth. Therefore, these impact factors should be discussed.

Many authors pay attention to the ground water used by crops in areas with shallow water table depth [11-13]. Yang et al. [14] monitored a vegetated lysimeter during a growing period of winter wheat and found that ground water contributed $16.6 \%$ of the total evapotranspiration when water table depth ranged from $1.6 \mathrm{~m}$ to $2.4 \mathrm{~m}$. Wu et al. [15] found that ground water contribution was about $50 \%$ of crop evapotranspiration using a soil water balance method. Luo and Sophocleous [16] compared the ground water evaporation under different water table depth scenarios with lysimeter experiments. In these works, the consumption of soil water was ignored, because the soil moisture contents were similar at the beginning and end of the crop growing season due to rich irrigation and precipitation or sufficient water supply from ground water. These conditions, however, do not exist when the water supply is insufficient during the crop growing season in arid areas with shallow water table depth. The study of Bandyopadhyay and Mallick [17] revealed that the soil water provided more water for crop growing than ground water did, $50.80 \mathrm{~mm}$ and $6.37 \mathrm{~mm}$ respectively, for the growing season of winter wheat in West Bengal, India, where the water table depth fluctuated between 0.8 $\mathrm{m}$ and $1.5 \mathrm{~m}$. Luo et al. [18] reported that the soil water storage utilization in the upper $60 \mathrm{~cm}$ and the ground water evaporation were about $100 \mathrm{~mm}$ and $40 \mathrm{~mm}$ of winter wheat, respectively, in an irrigation district of the Yellow River Basin, where the water table depth ranged from $0.5 \mathrm{~m}$ to $3.0 \mathrm{~m}$. Zhang and Wegehenkel [19] found that the capillary rise and the change of the soil water storage were $132.7 \mathrm{~mm} /$ year and $11.5 \mathrm{~mm} /$ year in an arable land in Müncheberg, Germany, where the water table depth was from $0.2 \mathrm{~m}$ to $3.0 \mathrm{~m}$. Soppe and Ayars [20] found that the ground water use and the change of soil water storage were $170 \mathrm{~mm}$ and $43 \mathrm{~mm}$ by lysimeter experiment with a water table depth of $0.9 \mathrm{~m}$. Hence, soil water and ground water are both important parts of crop water consumption and neither can be ignored in areas with shallow water table depth.

Since soil water and ground water have an intensive hydraulic connection in agricultural areas with shallow water table depth [21], it would be highly laborious to measure the soil moisture content from top soil to ground water, which are necessary data for estimating the quantity of soil-ground water storage utilization [22,23]. Two methods are usually used to calculate the soil-ground water storage utilization in practice. The first is to treat the phreatic evaporation or the ground water utilization as the quantity of the soil-ground water storage used by crops, due to the lack of soil moisture content data. Qu et al. [24] calculated the phreatic evaporation by empirical formula considering the relationship between the phreatic evaporation and the water table depth. Yang et al. [25] and Yu et al. [26] estimated the ground water utilization using the water table fluctuation method by multiplying the specific yield and changes of water table depth during the crop growing season. This method is reasonable 
when the soil moisture content has slight changes at the beginning and the end of the crop growing season. Otherwise, it may underestimate the quantity of water storage used by crops. The second method is to divide the soil profile into two zones at a certain depth. In the zone above the depth, the difference of the soil water storage at the beginning and end of the crop growing season is calculated by measured soil moisture data, since it is easy to be obtained. In the zone below the depth, the ground water utilization is obtained by using lysimeter experiments, tracer experiments, or numerical modelling approaches when there are no measured water table depth data [18,27-30], or by the water table fluctuation method where water table depth data are available [31,32]. However, the ground water utilization obtained by this experimental method can only represent a point or a small region [3], and the numerical modelling approaches have limitations because of the lack of data [33].

The crux of using the water table fluctuation method is to determine the specific yield, which is an important hydrogeological parameter connecting flow processes in the unsaturated and saturated zones [34]. This is defined as the volume of water that an aquifer releases from or takes into storage, per unit aquifer area, per unit change in water table depth [35]. Pumping tests are usually carried out to obtain the specific yield. However, the value obtained by pumping tests is usually lower than that obtained by water balance calculations [36], which is caused by the non-instantaneous drainage of pores in the unsaturated zone. Nwankwor et al. [37] found that the specific yield obtained by the type-curve method of Boulton was 0.07 , which was significantly smaller than the value of 0.25 obtained by the volume-balance method for a shallow sandy aquifer. The specific yield estimated by Malama [38] was smaller than 0.10 using the pumping test data of the Neuman model [39] at the Boise Hydro-geophysical Research Site in Boise, Idaho (US), while the value was 0.23 when using an alternative linearization of water table kinematic condition theory with the same pumping test data at this site. It is usually arbitrary to determine the value of specific yield when calculating the storage variation of ground water. The values of $0.15,0.07$ and 0.046 , were adopted by Gao et al. [40], Chen et al. [41] and Yang et al. [25], respectively, when using the water table fluctuation method for the same area, resulting in the large variation of calculated ground water utilization. The specific yield is critical to the calculation of soil-ground water storage utilization, while its determination is usually arbitrary, resulting in an inaccurate soil-ground water storage utilization. Therefore, it is important to determine the reasonable specific yield when using the water table fluctuation method.

To obtain the soil-ground water storage utilization during the crop growing season, 15 years' soil moisture content within a depth of $1 \mathrm{~m}$, and the water table depth dataset for Jiefangzha and its four subareas and a four year dataset from Yonglian, both located in arid northern China, are used in this study. The impact factors of soil-ground water storage utilization are discussed for helping in water management strategy. Then, to help in using the water table fluctuation method accurately, coefficients of soil-ground water storage utilization, ground water utilization and soil-ground water storage utilization below $1 \mathrm{~m}$ soil depth are analyzed. Finally, the contributions of soil-ground water storage utilization, ground water utilization and soil-ground water storage utilization below $1 \mathrm{~m}$ soil depth to the actual evapotranspiration (ET) are evaluated.

\section{Materials and Methods}

In this section, the observed data of the study areas used for calculating the soil-ground water storage utilization is presented in Section 2.1. The conception and calculation methods for soil-ground water storage utilization are then described in Section 2.2. The moving average method used for reducing random error and eliminating the noise of the soil-ground water storage utilization is shown in Section 2.3. To obtain the actual evapotranspiration for an analysis of the contribution of soil-ground water storage utilization to actual evapotranspiration, the water balance method is described in Section 2.4.

Specifically, the soil-ground water storage utilization is calculated in Jiefangzha and Yonglian. The soil moisture content is extended to the whole computational soil profile by a linear interpolation method, and then the soil-ground water storage utilization is calculated directly by the difference 
of water storage in the whole computational soil profile between the beginning and end of the crop growing season. Then the soil-ground water storage utilization is divided into soil water storage utilization and ground water utilization. The soil-ground water storage utilization below $1 \mathrm{~m}$ soil depth is also estimated since the maximum sampling depth is usually $1 \mathrm{~m}$ in many agricultural areas. Next, coefficients of soil-ground water storage utilization, ground water utilization and soil-ground water storage utilization below $1 \mathrm{~m}$ soil depth are analyzed. Finally, the contributions of soil-ground water storage utilization, ground water utilization and soil-ground water storage utilization below $1 \mathrm{~m}$ soil depth to the actual evapotranspiration (ET) are calculated.

\subsection{Study Area and Data Description}

The Hetao Irrigation District is located in the west of the Inner Mongolia Autonomous Region, China, as shown in Figure 1. The average annual precipitation and evaporation (measured by 20 $\mathrm{cm}$-diameter evaporation pans) are $152 \mathrm{~mm}$ and $2400 \mathrm{~mm}$, respectively. The evaporation is obtained from the China Meteorological Data Service Center (http://data.cma.gov.cn). Agricultural irrigation heavily relies on surface water resources diverted from the Yellow River. The water table depth of the Hetao Irrigation District varies from $0 \mathrm{~m}$ to $3.5 \mathrm{~m}$ over space and time, with an average annual value of $2.03 \mathrm{~m}$. The water table depth increases during the crop growing season in this area, because the water consumption is larger than the irrigation and precipitation. It is assumed that the study area does not have lateral hydraulic connection with surrounding regions, due to the gentle land surface and the small variation of water table depth in space [42], and that the hydrological processes (e.g., infiltration, evapotranspiration and deep percolation) mainly occur in the vertical direction. There is a freeze-thaw period from early December to late April in the Hetao Irrigation District.

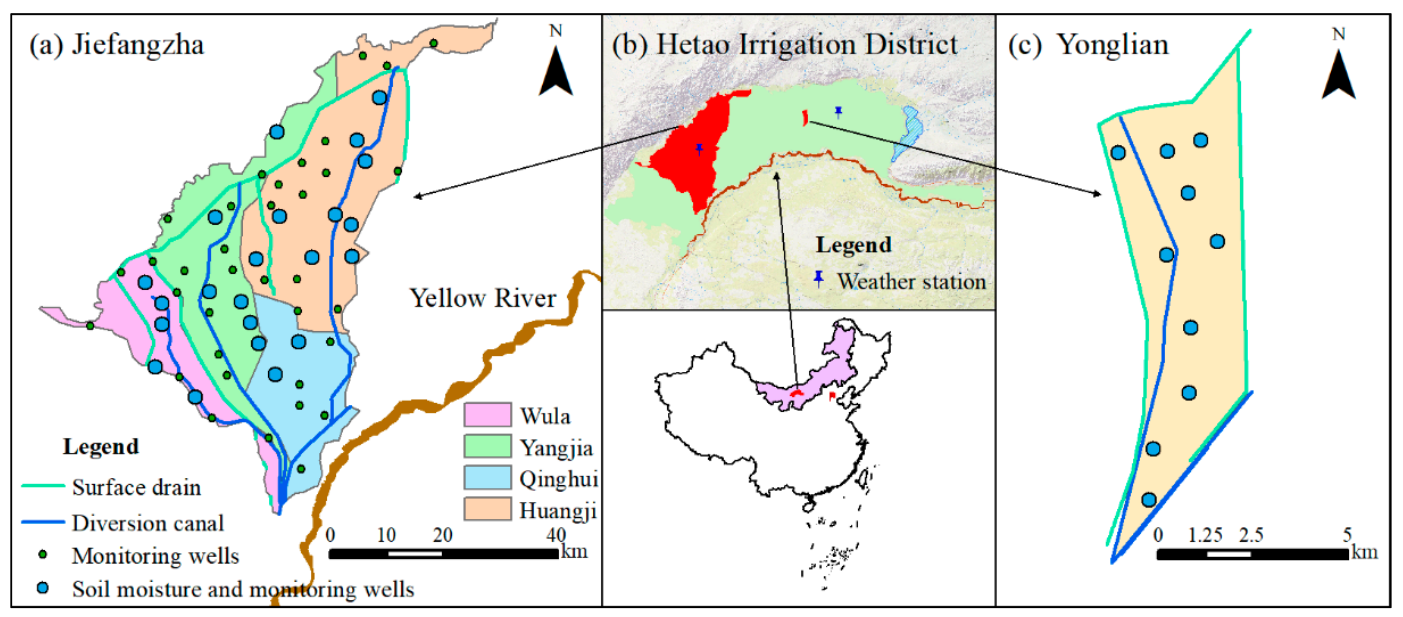

Figure 1. The location of the two study areas and the monitoring sites.

There are two experimental areas in the district, the Jiefangzha sub-district (JFZSD) and the Yonglian irrigation area (YIA). The Jiefangzha sub-district can be divided into four subareas, Wula, Yangjia, Huangji and Qinghui, by the trunk diversion canals, as shown in Figure 1a. The area of Jiefangzha is $2287 \mathrm{~km}^{2}$. The major soil textures in Jiefangzha sub-district are silt loam and sandy loam [9], and the saturated moisture contents are close in space. Therefore, the soil moisture content is treated as the same. The saturated soil moisture content is $0.46 \mathrm{~cm}^{3} / \mathrm{cm}^{3}$ in Jiefangzha as measured by the Water Resources Research Institute of Inner Mongolia. Wheat and maize are the main crops, and their growing seasons are from late March to late July and from the end of April to the end of September, respectively. The number of ground water and soil moisture content observation sites in each study area are shown in Table 1 . There are 57 ground water observation wells and 22 soil moisture content observation sites distributed across Jiefangzha, as shown in Figure 1a. All soil moisture content observation sites are adjacent to the ground water observation wells. The major crops are sown after the 
freeze-thaw period after the end of April in Hetao Irrigation District. Only wheat is sown at the end of March, and consumes little water, which can be ignored. So the end of April is chosen as the beginning of crop growing season in this study. The soil moisture content and water table depth at the end of the crop growing season are observed at the end of September. Five soil samples are collected at one monitoring site at the depths of $0 \sim 0.1 \mathrm{~m}, 0.1 \sim 0.2 \mathrm{~m}, 0.2 \sim 0.4 \mathrm{~m}, 0.4 \sim 0.7 \mathrm{~m}$ and $0.7 \sim 1.0 \mathrm{~m}$. The average soil moisture content within $1 \mathrm{~m}$ soil depth of Jiefangzha and its four subareas at the beginning and end of the crop growing season from 2003 to 2017 are displayed in Figure 2a,c. The average water table depth of Jiefangzha and its four subareas at the beginning and end of the crop growing season from 2003 to 2017 are displayed in Figure 2b,d. The water diversion during the crop growing season and non-growing season (which is also referred to as autumn irrigation) of Jiefangzha and its four subareas from 2003 to 2017 was provided by the Hetao Administration as shown in Figure 2e,g, respectively. Five weather stations are distributed in the Hetao Irrigation District from west to east. There are small differences of the meteorological data in the five weather stations when we analyze the data from 1961 to 2013. The previous study also showed that the representative distance of one weather station can be longer than $44 \mathrm{~km}$ in Hetao Irrigation District [43]. Therefore, one weather station can represent the meteorological condition of the whole area in Jiefangzha $\left(2287 \mathrm{~km}^{2}\right)$. The precipitation data for Jiefangzha during the crop growing season and non-growing season comes from the Hangjinghouqi meteorological station (shown in Figure 1b), which can be found in Figure 2f,h, respectively.

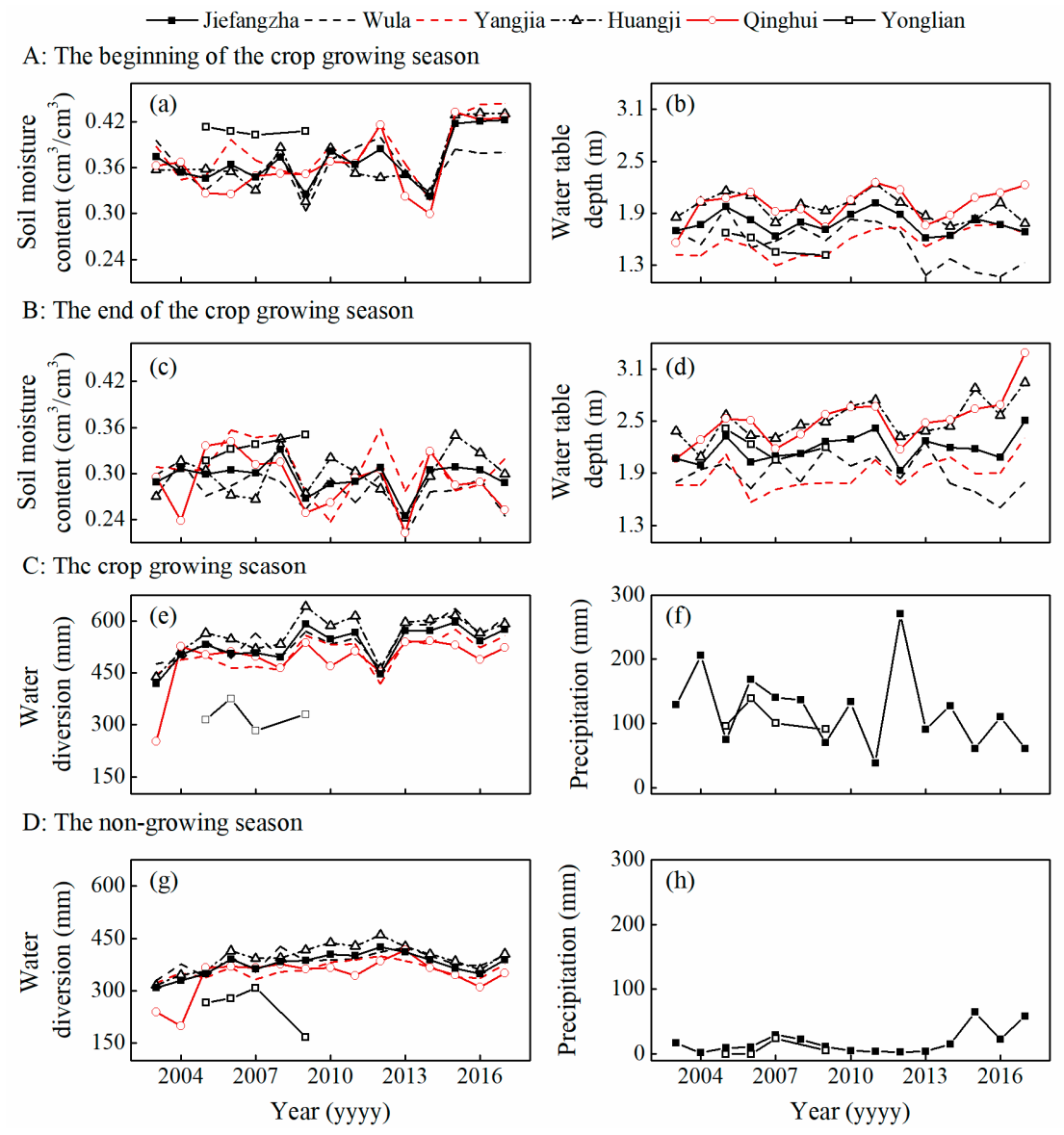

Figure 2. The measurements in Jiefangzha and its four subareas, and Yonglian. Measurements of (a) soil moisture content within $1 \mathrm{~m}$ soil depth and (b) water table depth at the beginning of the crop growing season. Measurements of (c) soil moisture content within $1 \mathrm{~m}$ soil depth and (d) water table depth at the end of the crop growing season. (e) The water diversion and (f) precipitation during the crop growing season. (g) The water diversion (autumn irrigation) and (h) precipitation during the non-growing season. 
Table 1. The number of ground water and soil moisture content observation sites in each study area.

\begin{tabular}{ccccc}
\hline Study Area & $\begin{array}{c}\text { Irrigation } \\
\text { Area }\left(\mathbf{k m}^{\mathbf{2}}\right)\end{array}$ & $\begin{array}{c}\text { Annual Average } \\
\text { Water Table } \\
\text { Depth } \mathbf{( m )}\end{array}$ & $\begin{array}{c}\text { Number of Soil } \\
\text { Moisture Content } \\
\text { Monitoring Sites }\end{array}$ & $\begin{array}{c}\text { Number of Water } \\
\text { Table Depth } \\
\text { Monitoring Wells }\end{array}$ \\
\hline Jiefangzha & 1243 & 1.634 & 22 & 57 \\
Wula & 195 & 1.392 & 5 & 10 \\
Yangjia & 430 & 1.451 & 6 & 17 \\
Huangji & 497 & 1.787 & 9 & 23 \\
Qinghui & 121 & 2.042 & 2 & 7 \\
Yonglian & 20 & 1.461 & 10 & 10 \\
\hline
\end{tabular}

The location of Yonglian irrigation area can be found in Figure 1c. The area of Yonglian is 29.7 $\mathrm{km}^{2}$. The major crop is sunflower, the growing season of which is from the end of May to late September. There are 10 soil moisture content observation sites in Yonglian, which are adjacent to the 10 ground water observation wells, as shown in Figure 1c. In Yonglian, there are only four years' dataset $(2005,2006,2007$ and 2009) available for calculation. The soil moisture content is measured at the depths of $0 \sim 0.1 \mathrm{~m}, 0.1 \sim 0.3 \mathrm{~m}, 0.3 \sim 0.5 \mathrm{~m}, 0.5 \sim 0.7 \mathrm{~m}$ and $0.7 \sim 1.0 \mathrm{~m}$. The average soil moisture contents within $1 \mathrm{~m}$ soil depth of Yonglian at the beginning and end of the crop growing season are displayed in Figure 2a,c. The average water table depths at Yonglian at the beginning and end of the crop growing season are shown in Figure $2 b, \mathrm{~d}$. The water diversion during the crop growing season and non-growing season was provided by the Hetao Administration as shown in Figure 2e,g, respectively. The precipitation data during the crop growing season and non-growing season comes from the Yonglian experiment station and the Wuyuan meteorological station (shown in Figure 1b), which can be found in Figure 2f,h, respectively.

\subsection{Calculation of Soil-Ground Water Storage Utilization}

Figure 3a shows the typical soil moisture profile at the beginning and end of crop growing season in the study area. The soil moisture profile at the beginning of the crop growing season is higher due to the water storage caused by the autumn irrigation. The water storage is consumed by transpiration and evaporation during the crop growing season, which leads to a lower soil moisture profile after harvest. The difference in water storage between the beginning and end of the crop growing season is regarded as the soil-ground water storage utilization during the crop growing season, which can be calculated by the following equation,

$$
\Delta W=W_{1}-W_{2}
$$

where $\Delta W$ is the soil-ground water storage utilization, $\mathrm{mm}$; and $W_{1}$ and $W_{2}$ are the water storages at the beginning and end of the crop growing season, $\mathrm{mm}$. 


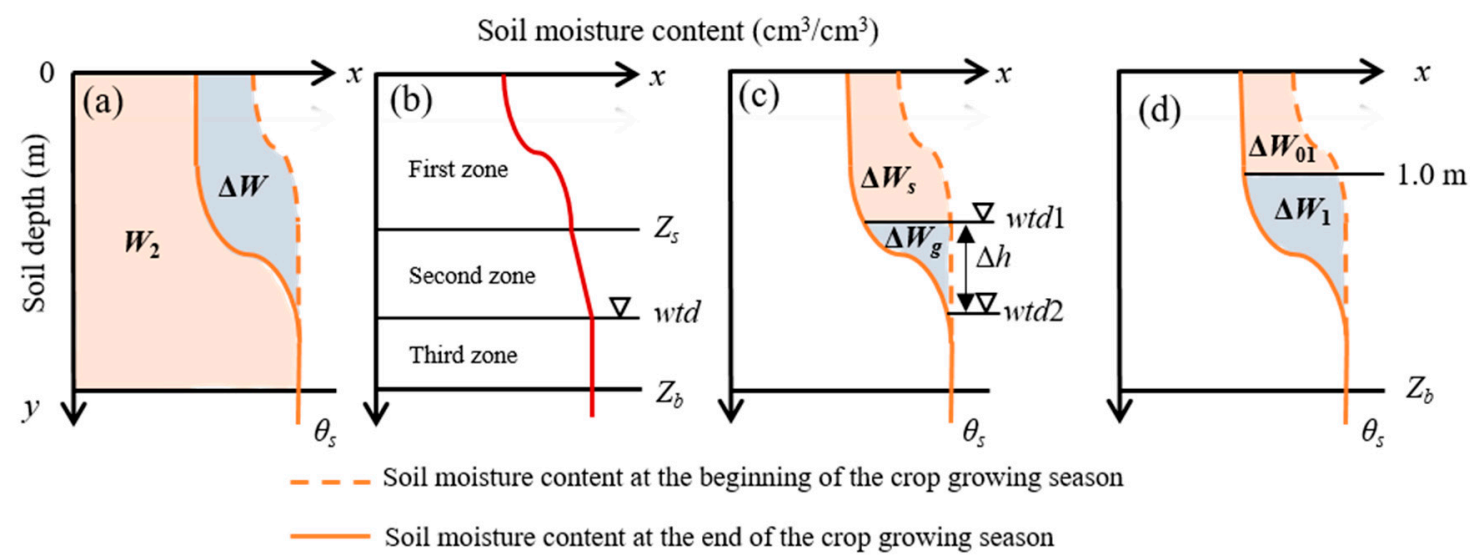

Figure 3. The schematic diagrams of (a) the soil moisture profiles at the beginning and end of the crop growing season, $(\mathbf{b})$ the three zones of the vertical soil profile for calculating the water storage (marked as $W$ ), (c) the soil water storage utilization (marked as $\Delta W_{s}$ ) and the ground water utilization (marked as $\Delta W_{g}$ ) and (d) the soil-ground water storage utilization below $1 \mathrm{~m}$ soil depth (marked as $\Delta W_{1}$ ) and above $1 \mathrm{~m}$ soil depth (marked as $\Delta W_{01}$ ). Note: $\Delta W$ is the soil-ground water storage utilization, $\mathrm{mm}$. $W_{2}$ is the water storages at end of the crop growing season. $w t d$ is the water table depth, mm. $w t d_{1}$ and $w t d_{2}$ are the water table depths at the beginning and end of the crop growing season, $\mathrm{mm}$. $\Delta h$ is the variation of water table depth during the crop growing season, $\mathrm{mm} . Z_{s}$ is the maximum sampling depth, $\mathrm{mm} . Z_{b}$ is the maximum computational depth, $\mathrm{mm}$.

The per unit area water storage $W$ of the vertical soil profile at a specific time is calculated as,

$$
W=\int_{0}^{Z_{b}} \theta d z=\sum_{i=1}^{m} \theta_{i} \times d_{i}
$$

where $Z_{b}$ is the maximum computational soil profile depth, $\mathrm{mm} ; \theta$ is the soil moisture content at the soil depth $z, \mathrm{~cm}^{3} \mathrm{~cm}^{-3} ; \theta_{i}$ is the soil moisture content of layer $i, \mathrm{~cm}^{3} \mathrm{~cm}^{-3} ; d_{i}$ is the thickness of the layer $i, \mathrm{~mm}$; and $m$ is the number of calculation layers. The $Z_{b}$ value is set as $3.5 \mathrm{~m}$ in this study since the maximum water table depth in Jiefangzha and Yonglian during the crop growing season is shallower than $3.5 \mathrm{~m}$. The $\theta_{i}$ value is the average soil water content of the soil moisture content monitoring sites in the study area.

The vertical soil profile, as shown in Figure $3 b$, is divided into three zones from top to bottom for calculating the water storage $W$. In the first zone, the calculation uses measured soil moisture content data, the second zone uses soil water content data obtained by a linear interpolation method, and the third zone below the water table depth uses the saturated soil moisture content. The soil-ground water storage utilization (marked as $\Delta W$ ) can be divided into two parts by the initial water table depth, which are the soil water storage utilization marked as $\Delta W_{s}$ and the ground water utilization $\Delta W_{g}$ as shown in Figure 3c. Besides, the soil-ground water storage utilization below $1 \mathrm{~m}$ soil depth (marked as $\Delta W_{1}$ ) is estimated as shown in Figure $3 \mathrm{~d}$, since the maximum sampling depth is usually $1 \mathrm{~m}$ in many agricultural areas and researchers usually consider $\Delta W_{1}$ as the ground water utilization [31]. To help in using the water table fluctuation method accurately, three coefficients are defined as follows for estimating the soil-ground water storage utilization, the ground water utilization and the soil-ground water storage utilization below $1 \mathrm{~m}$ soil depth:

$$
\begin{gathered}
\eta=\frac{\Delta W}{\Delta h} \\
\eta_{g}=\frac{\Delta W_{g}}{\Delta h}
\end{gathered}
$$




$$
\eta_{1}=\frac{\Delta W_{1}}{\Delta h}
$$

where $\eta$ is the coefficient of soil-ground water storage utilization, $\eta_{g}$ is the coefficient of ground water utilization, which is used to quantify the variation of water storage in the ground water fluctuation zone with the water table depth during the crop growing season, $\eta_{1}$ is the coefficient of soil-ground water storage utilization below $1 \mathrm{~m}$ soil depth, and $\Delta h$ is the increase of water table depth during the crop growing season, $\mathrm{mm}$.

Equations (3)-(5) are applied to arid and semi-arid regions where the water table depth at the end of the crop growing season is larger than that at the beginning of the crop growing season. Since the soil and ground water storage at the beginning of the crop growing season is mainly from the autumn irrigation in the study area, a coefficient referred to as the utilization efficiency of autumn irrigation $(\lambda)$ is proposed to quantify the contribution of the autumn irrigation to the water consumption of crops in the next year,

$$
\lambda=\frac{\Delta W}{Q_{a}}
$$

where $Q_{a}$ is the amount of autumn irrigation, $\mathrm{mm}$.

\subsection{Moving Average Method}

The moving average method is used to reduce random errors and eliminate the noise of temporal soil-ground water storage utilization [44]. For time series data $x$, the moving average value is calculated as follows [45],

$$
f_{j}=\frac{1}{K} \sum_{i=j-k}^{j+k} x_{i},(K=2 k+1, j=k+1, k+2, \cdots, N-k)
$$

where $f_{j}$ is the moving average soil-ground water storage utilization, $\mathrm{mm} ; K$ is the length of memory window, which is expressed as $K=2 k+1$ and $k$ is an integer. In this study, $K$ is adopted as 5 years. $x_{i}$ is the original time series of soil-ground water storage utilization, $\mathrm{mm}$, and $N$ is the length/number of the time series $x$.

\subsection{Water Balance Analysis to Estimate the Actual Evapotranspiration}

The water balance method is used to estimate the actual evapotranspiration during the crop growing season as follows [46],

$$
E T=\Delta W+I_{s}+P_{s}
$$

where $E T$ is the actual evapotranspiration in the field during the crop growing season, $\mathrm{mm} ; I_{s}$ is the amount of field irrigation water during the crop growing season, $\mathrm{mm}$; and $P_{S}$ is the precipitation during the crop growing season, $\mathrm{mm}$.

The contributions of soil-ground water storage utilization, soil-ground water storage utilization below $1 \mathrm{~m}$ soil depth and ground water utilization to the actual evapotranspiration (marked as $R W$, $R W_{1}$ and $R W_{g}$ ) can be calculated as,

$$
\begin{aligned}
R W & =\frac{\Delta W}{E T}, \\
R W_{1} & =\frac{\Delta W_{1}}{E T}, \\
R W_{g} & =\frac{\Delta W_{g}}{E T},
\end{aligned}
$$

These contributions ( $R W, R W_{1}$ and $R W_{g}$ ) can quantitatively distinguish the contribution of the soil-ground water storage utilization within different depths to the actual evapotranspiration. The soil-ground water storage utilization, soil-ground water storage utilization below $1 \mathrm{~m}$ soil depth and ground water utilization play different roles in actual evapotranspiration. So it is helpful to calculate 
different contributions for determining the contribution of every example of water storage utilization to the actual evapotranspiration.

\subsection{Statistical Indicators}

Classical statistical indicators, including average, maximum, minimum, standard deviation and coefficient of variation, are used to characterize the features of soil-ground water storage utilization and other variables. The coefficient of variation $\left(C_{v}\right)$ is used to explain the extent of the variability of variables, which can be calculated by [47],

$$
C_{v}=\frac{S_{x}}{\bar{X}}
$$

where $S_{x}$ is the standard deviation of the dataset, and $\bar{X}$ is the average value of the dataset.

\section{Results and Discussion}

\subsection{Results of the Soil-Ground Water Storage Utilization}

The soil-ground water storage utilizations at Jiefangzha and its four subareas (2003 2017) and Yonglian (2005, 2006, 2007 and 2009) during the crop growing season are shown in Figure 4a,b, and the statistical results are listed in Table 2. The average soil-ground water storage utilization of Jiefangzha in 2003 2017 is $121 \mathrm{~mm}$, varying from $57 \mathrm{~mm}$ to $229 \mathrm{~mm}$ and the standard deviation is $49 \mathrm{~mm}$. The average soil-ground water storage utilizations in Jiefangzha, Wula, Yangiia, Huangji, Qinghui and Yonglian are $121 \mathrm{~mm}, 126 \mathrm{~mm}, 113 \mathrm{~mm}, 124 \mathrm{~mm}, 185 \mathrm{~mm}$, and $117 \mathrm{~mm}$, respectively. The Qinghui subarea has the largest average soil-ground water storage utilization $(185 \mathrm{~mm})$, standard deviation $(86 \mathrm{~mm})$ and variation range $(307 \mathrm{~mm})$. One reason is that the Qinghui subarea obtained smaller water diversion and precipitation during the crop growing season, the average value of which is 357 $\mathrm{mm}$ from 2003 to 2017, smaller than those in Jiefangzha $(381 \mathrm{~mm})$ and other subareas. The average utilization efficiencies of autumn irrigation $(\lambda)$ in Jiefangzha, Wula, Yangjia, Huangji, Qinghui and Yonglian are $32.2 \%, 32.5 \%, 31.5 \%, 31.6 \%, 57.3 \%$ and $47.6 \%$ (shown in Table 2), respectively.

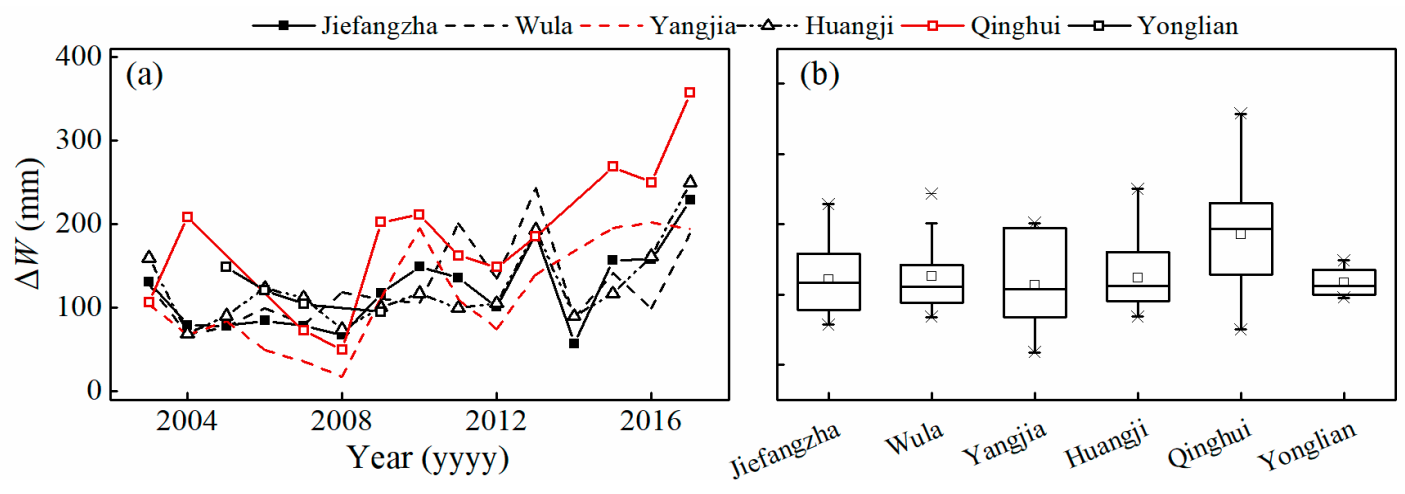

Figure 4. (a) The results and (b) the box plots of soil-ground water storage utilization $(\Delta W)$ during the crop growing season in Jiefangzha and its four subareas, and Yonglian. 
Table 2. Statistical results of soil-ground water storage utilizations and utilization efficiency of autumn irrigation of Jiefangzha and its four subareas, and Yonglian.

\begin{tabular}{|c|c|c|c|c|c|}
\hline \multirow{2}{*}{ Study Area } & \multicolumn{4}{|c|}{ Soil-Ground Water Storage Utilization (mm) } & \multirow{2}{*}{$\begin{array}{l}\text { Average Utilization } \\
\text { Efficiency of Autumn } \\
\text { Irrigation (\%) }\end{array}$} \\
\hline & Average & Maximum & Minimum & $\begin{array}{l}\text { Standard } \\
\text { Deviation }\end{array}$ & \\
\hline Jiefangzha & 121 & 229 & 57 & 49 & 32.2 \\
\hline Wula & 126 & 243 & 68 & 50 & 32.5 \\
\hline Yangija & 113 & 202 & 18 & 64 & 31.5 \\
\hline Huangji & 124 & 250 & 69 & 49 & 31.6 \\
\hline Qinghui & 185 & 357 & 50 & 86 & 57.3 \\
\hline Yonglian & 117 & 149 & 95 & 24 & 47.6 \\
\hline
\end{tabular}

To analyze the temporal variation of soil-ground water storage utilization, only the soil-ground water storage utilization in Jiefangzha and its four subareas from 2003 to 2017 are used since the data series of Yonglian is insufficient. The moving average soil-ground water storage utilization in Jiefangzha and its four subareas is shown in Figure 5a, in which an obvious increasing trend can be found. The soil-ground water storage utilization is increased by $7.00 \mathrm{~mm}, 7.33 \mathrm{~mm}, 12.01 \mathrm{~mm}, 4.85$ $\mathrm{mm}$, and $13.32 \mathrm{~mm}$ per year in Jiefangzha, Wula, Yangiia, Huangji and Qinghui, respectively. The data of Jiefangzha is taken as an example to analyze the reasons for the increasing trend. The water storage at the beginning of the crop growing season increases by $3.8 \mathrm{~mm}$ per year, contributing $54.6 \%$ to the increase of the soil-ground water storage utilization, and the water storage at the end of the crop growing season decreases by $3.2 \mathrm{~mm}$ per year, contributing $45.4 \%$ to the increase of the soil-ground water storage utilization, as shown in Figure $5 b$.
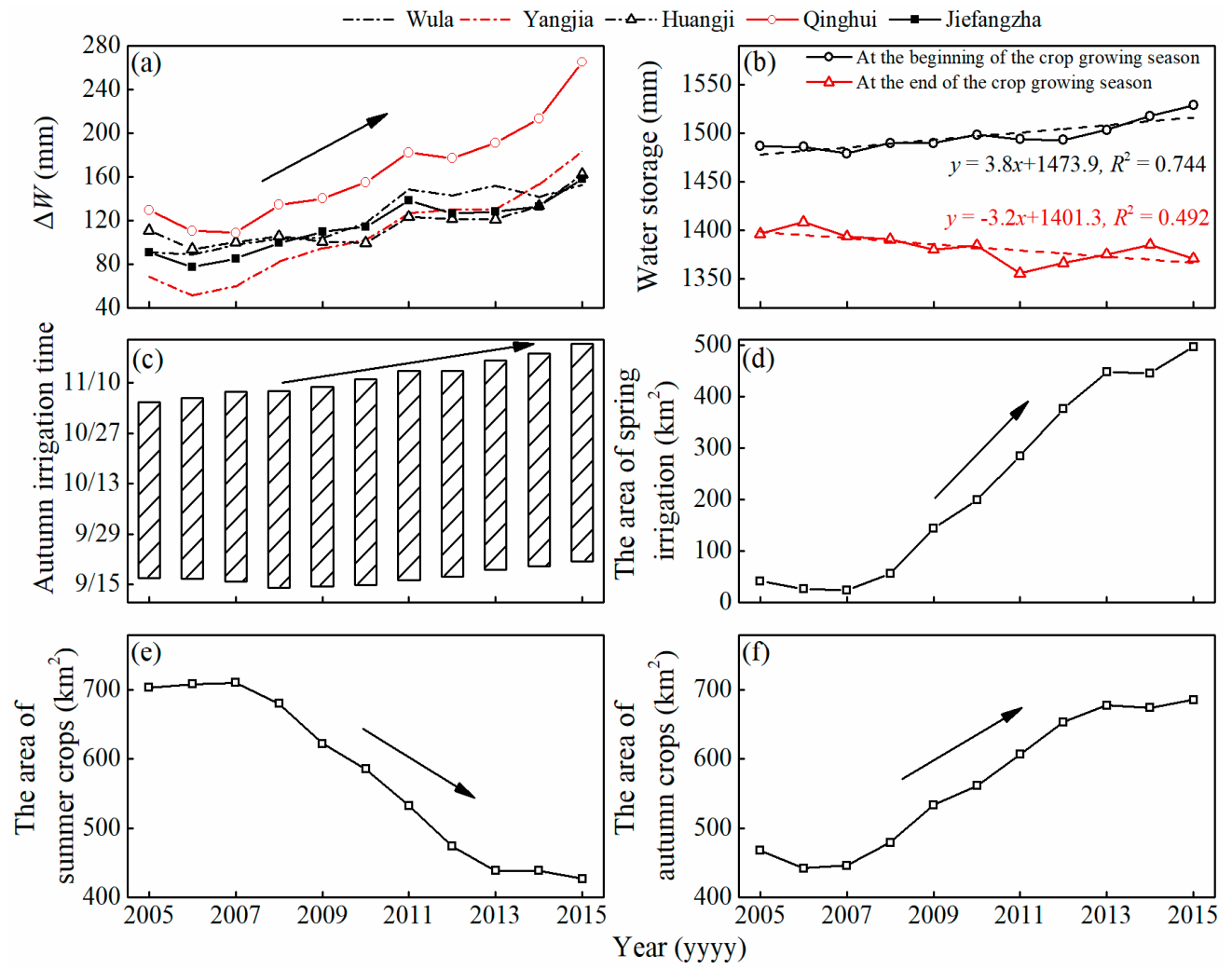

Figure 5. The moving average results of (a) the soil-ground water utilization $(\Delta W)$ in Jiefangzha and its four subareas, (b) the water storages at the beginning and end of the crop growing season in Jiefangzha, (c) the autumn irrigation time in Jiefangzha, (d) the area of spring irrigation in Jiefangzha, (e) the area of summer crops in Jiefangzha, and (f) the area of autumn crops in Jiefangzha. 


\subsection{The Impact Factors on Soil-Ground Water Storage Utilization}

The correlations between the soil-ground water storage utilization in Jiefangzha and the eight impact factors are listed in Table 3. It can be found that there are five impact factors that have significant correlation with the soil-ground water storage utilization at the significance level of 0.01 or 0.05 . The factors are the autumn irrigation time $\left(T_{a i}\right)$, the area of the spring irrigation $\left(S_{i}\right)$, the area of summer crops $\left(S_{s}\right)$, the area of autumn crops $\left(S_{a}\right)$ and the increase of water table depth during the crop growing season $(\Delta h)$. The autumn irrigation time has a significant positive relationship with the soil-ground water storage utilization $(R=0.647, P=0.009)$. The autumn irrigation occurs in 2003 2007 and 2013 2017 from 23 September 31 October and 3 October 9 November as shown in Figure 5c. The delayed autumn irrigation time leads to the higher soil moisture content at the beginning of the next crop growing season, so the water storage at the beginning of crop growing season would increase causing the increase of soil-ground water storage. The area of the spring irrigation has a positive relationship with the soil-ground water storage utilization $(R=0.641, P=0.010)$. The spring irrigation area increases from $42 \mathrm{~km}^{2}$ in 2003 2007 to $497 \mathrm{~km}^{2}$ in 2013 2017 as shown in Figure 5d, and the larger area of the spring irrigation leads to the larger water storage at the beginning of crop growing season. The area of the summer crops has a significant negative correlation with the soil-ground water storage utilization $(R=-0.572, P=0.026)$, while there is a significant positive correlation between the area of the autumn crops and the soil-ground water storage utilization $(R=0.604, P=0.017)$. As shown in Figure $5 \mathrm{e}, \mathrm{f}$, the area of summer crops is decreasing and the area of autumn crops is increasing in Jiefangzha, causing the increase of water consumption in August and September and the decrease of water storage at the end of the crop growing season. This indicates that the adjustment of planting structure can significantly impact the soil-ground water storage utilization. There is a significant positive relationship between the increase of water table depth during the crop growing period and soil-ground water storage utilization $(R=0.554, P=0.032)$, which also can be found in Figure $6 \mathrm{a}$.

Table 3. Correlation between the soil-ground water storage utilization and the eight impact factors.

\begin{tabular}{ccccccccc}
\hline Impact Factors & $T_{a i}$ & $S_{i}$ & $S_{s}$ & $S_{a}$ & $\Delta h$ & $I_{a}+P_{a}$ & $I_{s}+P_{s}$ & $\boldsymbol{h}$ \\
\hline Correlation coefficient $(R)$ & $0.647^{* *}$ & $0.641^{*}$ & $-0.572^{*}$ & $0.604^{*}$ & $0.554^{*}$ & 0.479 & -0.403 & 0.333 \\
Significance level $(P)$ & 0.009 & 0.010 & 0.026 & 0.017 & 0.032 & 0.071 & 0.136 & 0.225 \\
\hline
\end{tabular}

Note: (1) $T_{a i}$ is the autumn irrigation time. $S_{i}$ is the area of the spring irrigation, mm. $S_{s}$ is the area of summer crops, $\mathrm{km}^{2} . S_{a}$ is the area of autumn crops, $\mathrm{km}^{2} . \Delta h$ is the increase of water table depth during the crop growing season, $\mathrm{mm} . I_{a}+P_{a}$ is the total water supply during the non-growing season, $\mathrm{mm} ; I_{a}$ is the field irrigation water during the non-growing season, $\mathrm{mm} ; P_{a}$ is the precipitation during the non-growing season, $\mathrm{mm}$. $I_{s}+P_{s}$ is the total water supply during the crop growing season, $\mathrm{mm} ; I_{S}$ is the field irrigation water during the crop growing season, $\mathrm{mm}$; $P_{s}$ is the precipitation during the crop growing season, $\mathrm{mm} . \bar{h}$ is the average water table depth during the crop growing season, $\mathrm{mm}$. (2) * Correlation is significant at the 0.05 level (2-tailed), and ${ }^{* *}$ Correlation is significant at the 0.01 level (2-tailed).

The correlation of the other three impact factors (the total water supply during the non-growing season $I_{a}+P_{a}$, the total water supply during the crop growing season $I_{s}+P_{s}$ and the average water table depth during the crop growing season $\bar{h}$ ) with the soil-ground water storage utilization are not significant at the 0.05 level. It can be found that there is a positive relationship between the total water supply during the non-growing season and soil-ground water storage utilization $(R=0.479, P$ $=0.071)$. When the total water supply during the non-growing season increases, the water storage at the beginning of crop growing season will increase. However, as shown in Figure $6 \mathrm{~b}$, the total water supply during the non-growing season is very stable at $200 \mathrm{~mm}-210 \mathrm{~mm}$ from 2006 to 2014, which caused the poor correlation with the increase of soil-ground water storage utilization in these years. The total water supply during the crop growing season has a negative relationship with the soil-ground water storage utilization $(R=-0.403, P=0.136)$. The linear negative correlation is obvious when the total water supply during the crop growing season is larger than $400 \mathrm{~mm}$, close to the crop water requirement of major crops in this area, which means that crops can obtain sufficient water by 
irrigation and precipitation causing less soil-ground water storage utilization, as shown in Figure 6c. In the works of Chen et al. [31] and Liu et al. [3], there is also a negative relationship between the ground water contribution to evapotranspiration and the total water supply during the crop growing season. The positive relationship between the average water table depth during the crop growing season $\bar{h}$ and the soil-ground water storage utilization is not significant, with $R=0.333$ and $P=0.225$. The relationship between the soil-ground water storage utilization and the average water table depth is quadratic as shown in Figure 6d. A critical water table depth $(2080 \mathrm{~mm})$ exists, before which the relationship between the soil-ground water storage utilization and the average water table depth is positive, and then it becomes negative. The critical water table depth was also found by Chen et al. [41]. The existence of the critical water table depth indicates that the soil-ground water storage utilization would increase first, and then decrease in the future with a decrease of water diversion from Yellow river, which is considered to increase the water table depth $[48,49]$.
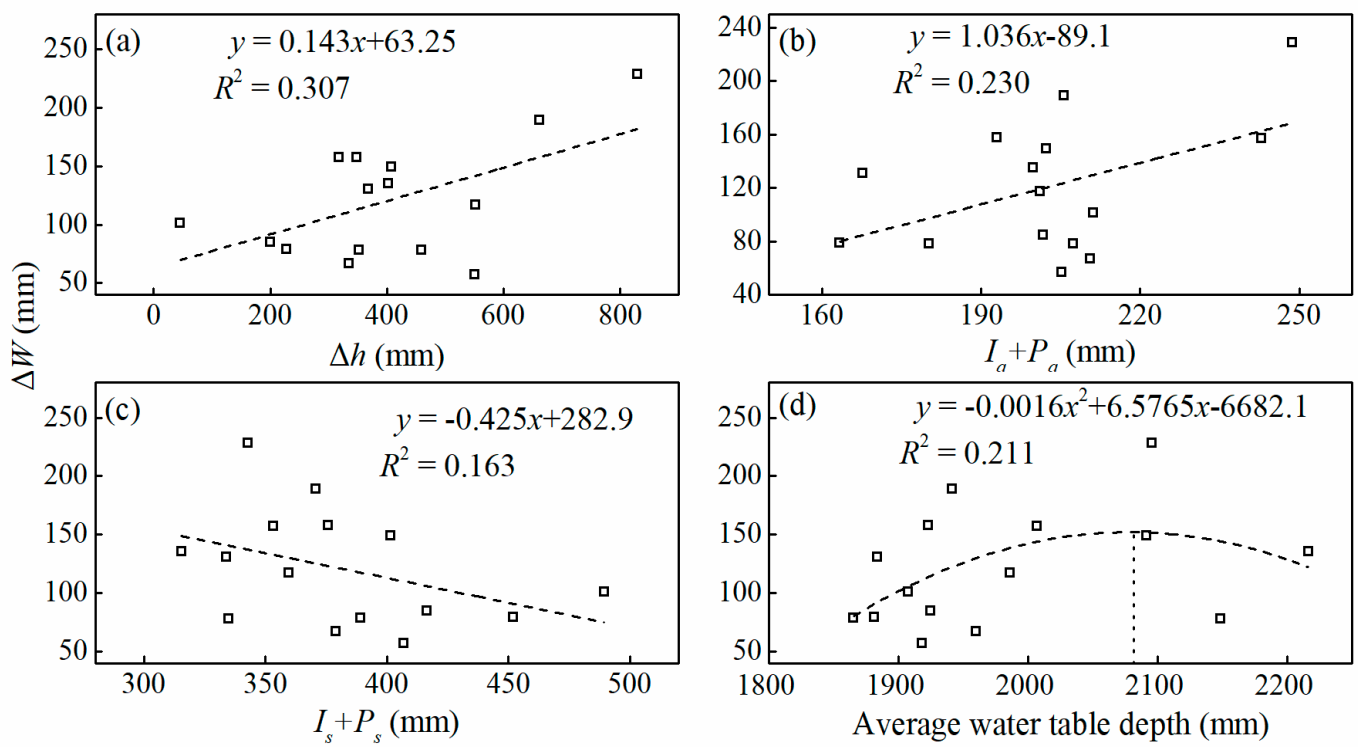

Figure 6. The relationships of (a) the increase of the water table depth during the crop growing season $(\Delta h),(\mathbf{b})$ the total water supply during the non-growing season $\left(I_{a}+P_{a}\right)$, (c) the total water supply during the crop growing season $\left(I_{S}+P_{S}\right)$, and (d) the average water table depth during the crop growing season $\bar{h}$ with the soil-ground water storage utilization $(\Delta W)$.

In general, the soil-ground water storage utilization is significantly affected by the autumn irrigation time, the area of the spring irrigation, the area of summer crops, the area of autumn crops, and the variation of water table depth during the crop growing season. Changing the autumn irrigation scheme and planting structure would be effective ways to increase soil-ground water storage utilization. When the water supply during the crop growing season is insufficient, delaying the autumn irrigation time, increasing the amount of autumn irrigation and increasing the area of spring irrigation are useful strategies to help increase the soil-ground water storage before the crop growing period. Meanwhile, our suggestions are to adjust the planting structure, increase the area of autumn crops, and reduce the area of summer crops, which can help crops use more soil-ground water resources for water consumption during the crop growing season.

\subsection{Results of Soil Water Storage Utilization, Ground Water Utilization, Soil-Ground Water Storage Utilization below and above $1 \mathrm{~m}$ Soil Depth and the Three Coefficients}

In this section, the two components of soil-ground water storage utilization are estimated, including the soil water storage utilization $\Delta W_{s}$ and the ground water utilization $\Delta W_{g}$, and the soil-ground water storage utilization below $1 \mathrm{~m}$ soil depth $\Delta W_{1}$ and above $1 \mathrm{~m}$ soil depth $\Delta W_{01}$. The water table depth at 
the end of the crop growing season is larger than that at the beginning of the crop growing season in Jiefangzha and Yonglian, and the $\Delta h$ is larger than 0 , so Equations (3)-(5) can be used in this research. Then, the three coefficients, the coefficient of soil-ground water storage utilization $\eta$, the coefficient of ground water utilization $\eta_{g}$ and the coefficient of soil-ground water storage utilization below $1 \mathrm{~m}$ soil depth $\eta_{1}$, are calculated. The results of $\Delta W_{s}$ and $\Delta W_{g}$ and their contributions to the soil-ground water storage utilization $\Delta W$ in Jiefangzha and Yonglian are shown in Figure 7, the statistical results of which are listed in Table 4. The average soil water storage utilization $\Delta W_{s}$ is $112 \mathrm{~mm}$, which accounts for $92.6 \%$ of the soil-ground water storage utilization $\Delta W$, while the ground water utilization $\Delta W_{g}$ is $9 \mathrm{~mm}(7.4 \%$ of the $\Delta W)$ in Jiefangzha. In Yonglian, the average $\Delta W_{s}$ is $98 \mathrm{~mm}$, which accounts for $83.0 \%$ of the $\Delta W$, and the average $\Delta W_{g}$ is $19 \mathrm{~mm}(17.0 \%$ of the $\Delta W)$. The contribution of soil water storage utilization during the crop growing season is larger than $80 \%$ in this study, which proves that the soil water storage utilization is the main part of the soil-ground water storage utilization. The results illustrate that the variation in water storage in the ground water fluctuation zone during the crop growing season is small. due to the capillary siphoning phenomenon, which leads to slight soil moisture content variation near the saturated zone. The ground water utilization $\Delta W_{g}$ has a significant positive relationship ( $R=0.961, P=0.000$ ) with the increase of water table depth during the crop growing season in Jiefangzha, as shown in Figure 8a. The coefficient of ground water utilization $\eta_{g}$ is shown in Figure 9, the statistical results of which are listed in Table 4. The coefficient of ground water utilization $\eta_{g}$ ranges from 0.008 to 0.04 with the standard deviation of 0.01 , and the average value is 0.026 in Jiefangzha. In Yonglian, the average coefficient of ground water utilization is 0.028 . In the works of $\mathrm{Xu}$ et al. [9] and Yue et al. [50], the coefficients of ground water utilization were 0.039 and 0.086 for estimating the variation of the ground water storage in Jiefangzha and Yichang, both of which are located in the Hetao Irrigation District. They chose these values according to the specific yield based on the hydrogeological studies. However, it can be found that the adopted values in the works of $\mathrm{Xu}$ et al. [9] and Yue et al. [50] would overestimate the variation of ground water storage. Therefore, in calculating the variation of ground water storage, the coefficient of ground water utilization should be carefully selected, which is smaller than the specific yield.

A: The results in Jiefangzha

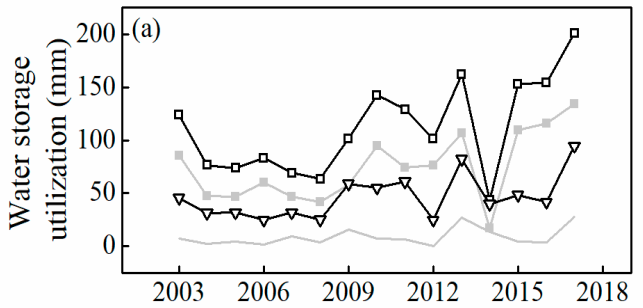

B: The results in Yonglian

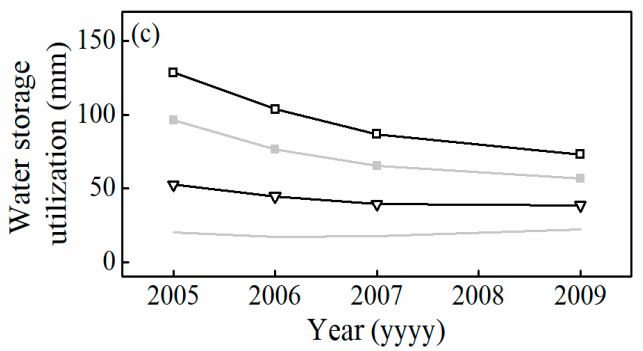

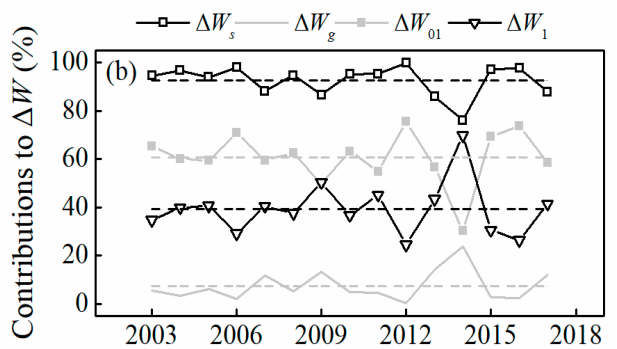

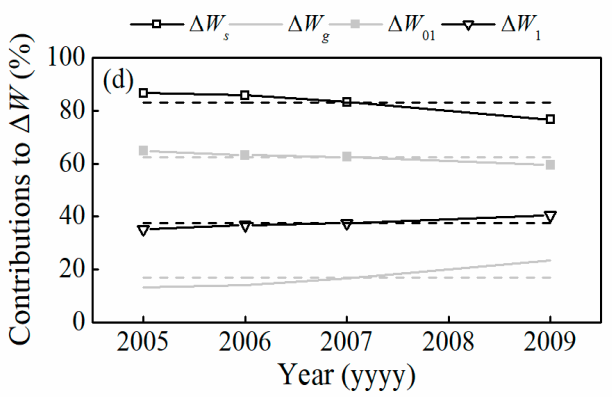

Figure 7. The results of soil water storage utilization $\left(\Delta W_{s}\right)$, ground water utilization $\left(\Delta W_{g}\right)$, soil-ground water storage utilization below $1 \mathrm{~m}$ soil depth $\left(\Delta W_{1}\right)$, soil-ground water storage utilization above $1 \mathrm{~m}$ soil depth $\left(\Delta W_{01}\right)$ and their contributions to the soil-ground water storage utilization $(\Delta W)$ in Jiefangzha and Yonglian. (a) and (c) The results of these water storage utilizations in Jiefangzha and Yonglian, respectively. (b) and (d) The results of the contributions of water storage utilizations to soil-ground water storage utilization $(\Delta W)$ in Jiefangzha and Yonglian, respectively. 
Table 4. Statistical results of $\Delta W_{s}, \Delta W_{g}, \Delta W_{01}, \Delta W_{1}, \eta_{g}, \eta_{1}$ and $\eta$ in Jiefangzha and Yonglian.

\begin{tabular}{ccccccccccc}
\hline & \multicolumn{9}{c}{ Jiefangzha } & \multicolumn{3}{c}{ Yonglian } \\
\cline { 2 - 10 } Variables & Average & Maximum & Minimum & $\begin{array}{c}\text { Standard } \\
\text { Deviation }\end{array}$ & $C_{v}$ & Average & Maximum & Minimum & $\begin{array}{c}\text { Standard } \\
\text { Deviation }\end{array}$ & $C_{v}$ \\
\hline$\Delta W_{s}$ & 112 & 201 & 43 & 45 & 0.399 & 98 & 129 & 73 & 24 \\
$\Delta W_{g}$ & 9 & 28 & 0 & 9 & 0.957 & 19 & 22 & 17 & 2 & 0.245 \\
$\Delta W_{01}$ & 74 & 134 & 17 & 33 & 0.442 & 74 & 96 & 57 & 17 & 0.233 \\
$\Delta W_{1}$ & 46 & 95 & 25 & 21 & 0.451 & 44 & 52 & 39 & 6 & 0.147 \\
$\eta_{\mathrm{g}}$ & 0.026 & 0.040 & 0.008 & 0.010 & 0.368 & 0.028 & 0.029 & 0.027 & 0.001 & 0.035 \\
$\eta_{1}$ & 0.111 & 0.152 & 0.069 & 0.027 & 0.243 & 0.065 & 0.072 & 0.050 & 0.010 & 0.161 \\
$\eta$ & 0.271 & 0.497 & 0.104 & 0.114 & 0.419 & 0.174 & 0.201 & 0.122 & 0.036 & 0.208 \\
\hline
\end{tabular}

Note: $\Delta W_{s}$ is the soil water storage utilization, mm. $\Delta W_{g}$ is the ground water utilization, $\mathrm{mm} . \Delta W_{01}$ is the soil-ground water storage utilization above $1 \mathrm{~m}$ soil depth, mm. $\Delta W_{1}$ is the soil-ground water storage utilization below $1 \mathrm{~m}$ soil depth, $\mathrm{mm} . \eta_{g}$ is the coefficient of ground water utilization. $\eta_{1}$ is the coefficient of soil-ground water storage utilization below $1 \mathrm{~m}$ soil depth. $\eta$ is the coefficient of soil-ground water storage utilization. $C_{v}$ is the coefficient of variation.
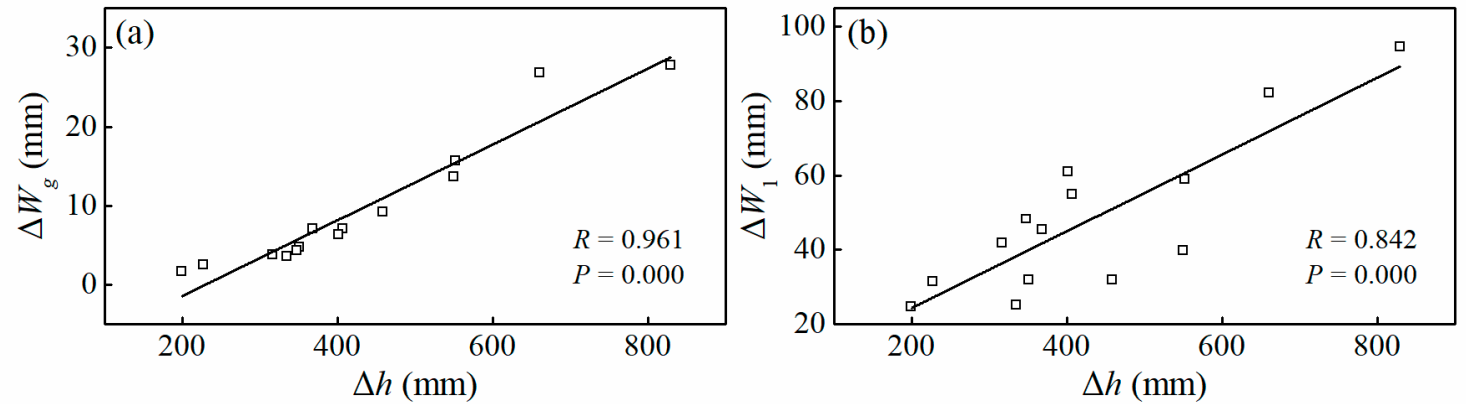

Figure 8. The correlation between (a) ground water utilization $\left(\Delta W_{g}\right)$ and (b) soil-ground water storage utilization below $1 \mathrm{~m}$ soil depth $\left(\Delta W_{1}\right)$ with the increase of the water table depth during the crop growing season $(\Delta h)$ in Jiefangzha.
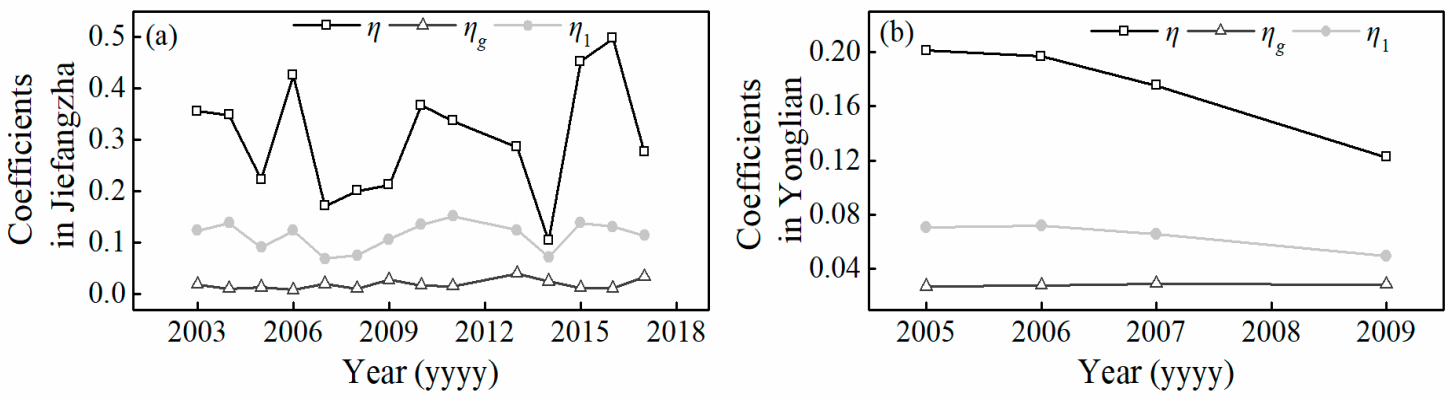

Figure 9. The results of the coefficient of soil-ground water storage utilization $(\eta)$, the coefficient of soil-ground water storage utilization below $1 \mathrm{~m}$ soil depth $\left(\eta_{1}\right)$ and the coefficient of ground water utilization ( $\eta_{g}$ ) of (a) Jiefangzha from 2003 to 2017 (except 2012) and (b) Yonglian in 2005, 2006, 2007 and 2009.

The results of average soil-ground water storage utilization above and below $1 \mathrm{~m}$ soil depth $\left(\Delta W_{01}\right.$ and $\Delta W_{1}$ ) and their contributions to soil-ground water storage utilization $\Delta W$ in Jiefangzha and Yonglian are shown in Figure 7, the statistical results of which are listed in Table 4 . The average $\Delta W_{01}$ is $74 \mathrm{~mm}$, accounting for $60.6 \%$ of the soil-ground water storage utilization $\Delta W$, and the $\Delta W_{1}$ is $47 \mathrm{~mm}$, accounting for $39.4 \%$ of $\Delta W$ in Jiefangzha. In Yonglian, the average $\Delta W_{01}$ and $\Delta W_{1}$ are $74 \mathrm{~mm}$ and 44 $\mathrm{mm}$, accounting for $62.5 \%$ and $37.5 \%$ of $\Delta W$. The contribution of soil-ground water storage utilization above $1 \mathrm{~m}$ soil depth is larger than $60 \%$, which indicates that the utilization of soil-ground water storage is mainly from the soil depth above $1 \mathrm{~m}$. There is a significant positive relationship $(R=0.842$, $P=0.000$ ) between the soil-ground water utilization below $1 \mathrm{~m}$ soil depth $\Delta W_{1}$ and the increase of the water table depth during the crop growing season in Jiefangzha, as shown in Figure 8b. The coefficient 
of soil-ground water storage utilization below $1 \mathrm{~m}$ soil depth $\eta_{1}$ is shown in Figure 9 , the statistical results of which are displayed in Table 4 . The coefficient of the soil-ground water storage utilization below $1 \mathrm{~m}$ soil depth $\eta_{1}$ ranges from 0.069 to 0.152 with the $C_{v}$ value of 0.243 and the average value is 0.111 in Jiefangzha. In Yonglian, the average $\eta_{1}$ is 0.065 . The maximum sampling depth is usually $1 \mathrm{~m}$ in many agricultural areas. So this coefficient is an important parameter to estimate the variation of the water storage resource below $1 \mathrm{~m}$ soil depth. The value used for calculating the soil-ground water storage utilization below $1 \mathrm{~m}$ soil depth by Chen et al. [41] and Liu et al. [3] was 0.07 in Jiefangzha. It can be found that the calculated soil-ground water storage utilization below $1 \mathrm{~m}$ soil depth would induce a $37 \%$ error.

The coefficient of soil-ground water storage utilization $\eta$ is shown in Figure 9, the statistical results of which are listed in Table 4 . The coefficient of the soil-ground water storage utilization $\eta$ ranges from 0.104 to 0.497 with a standard deviation of 0.114 . The coefficient of the soil-ground water storage utilization $\eta$ varies greatly over the years. The average coefficients of soil-ground water storage utilization are 0.271 and 0.172 in Jiefangzha and Yonglian, respectively. This value is consistent with the work of Steinwand et al. [51], where the coefficients were 0.18 for the sandy site and 0.28 for the clay loam site. This value is much larger than the specific yield used for calculating the variation of the soil-ground water storage during the crop growing season, which is obtained by pumping tests due to the non-instantaneous drainage in the vadose zone and aquifer compressibility $[36,52,53]$. Therefore, the specific yield from the pumping test cannot be used directly for calculation of the soil-ground water storage utilization, which could underestimate the results.

In general, the three coefficients are ranked as $\eta>\eta_{1}>\eta_{\mathrm{g}}$, and there is a great difference among them. So one should be careful to choose suitable coefficients when calculating the variation of soil-ground water storage.

3.4. Contributions of Ground Water Utilization, Soil-Ground Water Storage Utilization below $1 \mathrm{~m}$ Soil Depth, Soil-Ground Water Storage Utilization to the Actual Evapotranspiration

The results of the actual evapotranspiration (ET) during the crop growing season in Jiefangzha (2003 2017) and Yonglian (2005 2009) are shown Figure 10a,c, the statistical results of which are listed in Table 5. The average calculated actual evapotranspiration during the crop growing season is 502 $\mathrm{mm}$ from 2003 to 2017 in Jiefangzha, ranging from $413 \mathrm{~mm}$ to $591 \mathrm{~mm}$. In Yonglian, the average calculated actual evapotranspiration is $485 \mathrm{~mm}$ from 2005 to 2009, ranging from $431 \mathrm{~mm}$ to $561 \mathrm{~mm}$. The contributions of soil-ground water storage utilization $(R W)$, soil-ground water storage utilization below $1 \mathrm{~m}$ soil depth $\left(R W_{1}\right)$ and ground water utilization $\left(R W_{g}\right)$ to the actual evapotranspiration in Jiefangzha and Yonglian are shown in Figure 10b,d, the statistical results of which are listed in Table 5. In Jiefangzha, the average contribution of soil-ground water storage utilization to the actual evapotranspiration $(R W)$ is $23.7 \%$, which demonstrates that the soil-ground water storage utilization is an important source for crop water consumption. The average contribution of soil-ground water storage utilization below $1 \mathrm{~m}$ soil depth to the actual evapotranspiration $\left(R W_{1}\right)$ is $9.2 \%$ and the average contribution of ground water utilization to the actual evapotranspiration $\left(R W_{g}\right)$ is $1.8 \%$ in Jiefangzha. The $R W$ in Jiefangzha has an increasing trend from 2013 to 2017, which increases from $19.1 \%$ in $2003 \sim 2007$ to $29.3 \%$ in 2013 2017. The $R W$ has a significant negative relationship with precipitation during the crop growing season $(R=-0.621, P=0.013)$. Due to the larger precipitation during the crop growing season in 2012 and 2014, the $R W$ of 2012 and 2014 are smaller than that in 2011 2017. In Yonglian, the average $R W, R W_{1}$ and $R W_{g}$ are $24.2 \%, 9.0 \%$ and $4.0 \%$, respectively. It can be found that the average contribution of soil-ground water storage utilization below $1 \mathrm{~m}$ soil depth to the actual evapotranspiration is over $9.0 \%$ and the contribution of soil-ground water storage utilization to the actual evapotranspiration is over $23.5 \%$. The results of Gao et al. [40] are consistent with the results of this study; the average contribution of soil-ground water storage utilization below $0.5 \mathrm{~m}$ soil depth to the actual evapotranspiration were $25.6 \%, 12.0 \%$ and $15.2 \%$ in upper, middle and lower reaches of Hetao Irrigation District, respectively, which is within the range of $R W_{1}(9.0 \%)$ to $R W(23.5 \%)$ in this 
study. These results indicate that storing water resources during the non-growing season by irrigation or precipitation is a useful way to alleviate the water shortage during the crop growing season in arid agricultural regions with shallow water table depth.

A:Results in Jiefangzha

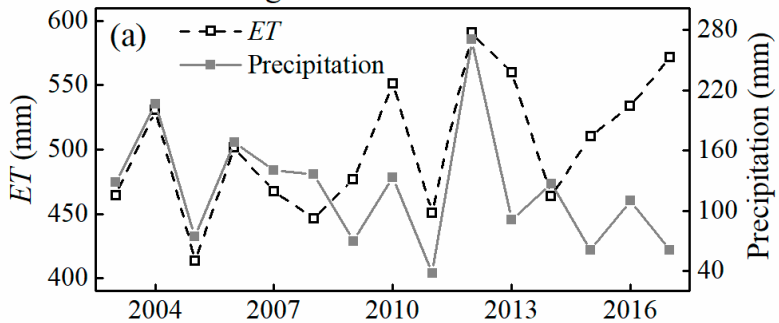

$\mathrm{B}:$ Results in Yonglian

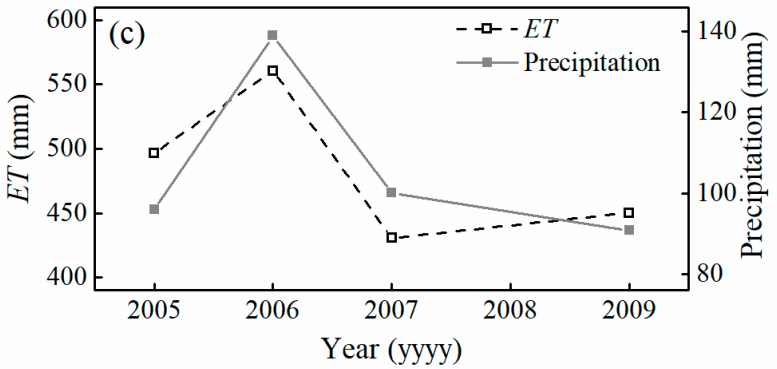

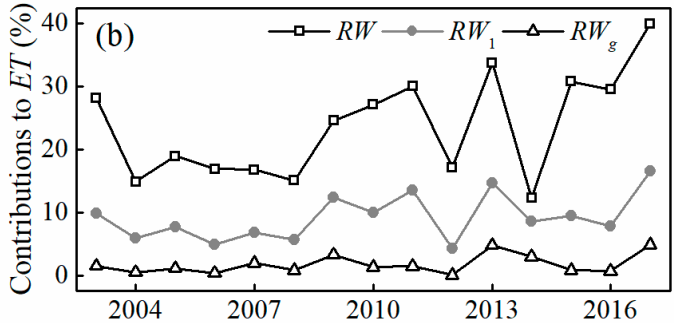

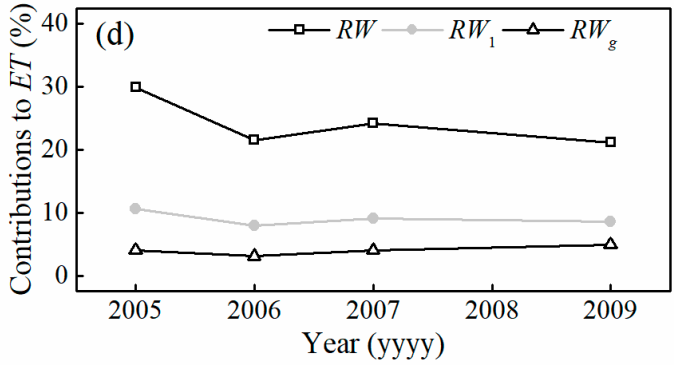

Figure 10. Results of the actual evapotranspiration $(E T)$, precipitation and contributions of ground water utilization $\left(R W_{g}\right)$, soil-ground water storage utilization below $1 \mathrm{~m}$ soil depth $\left(R W_{1}\right)$, and soil-ground water storage utilization $(R W)$ to the actual evapotranspiration in Jiefangzha and Yonglian. (a) and (c) Results of the actual evapotranspiration (ET) and precipitation in Jiefangzha and Yonglian, respectively. (b) and (d) Results of the contributions of the water storage utilizations to the actual evapotranspiration in Jiefangzha and Yonglian, respectively.

Table 5. Statistical results of $E T, R W, R W_{1}$ and $R W_{\mathrm{g}}$ in Jiefangzha and Yonglian.

\begin{tabular}{ccccccccc}
\hline \multirow{2}{*}{ Variables } & \multicolumn{4}{c}{ Jiefangzha } & \multicolumn{4}{c}{ Yonglian } \\
\cline { 2 - 8 } & Average & Maximum & Minimum & $\begin{array}{c}\text { Standard } \\
\text { Deviation }\end{array}$ & Average & Maximum & Minimum & $\begin{array}{c}\text { Standard } \\
\text { Deviation }\end{array}$ \\
\hline$E T$ & 502 & 591 & 413 & 53 & 485 & 561 & 431 & 58 \\
$R W$ & $23.75 \%$ & $40.00 \%$ & $12.31 \%$ & $8.31 \%$ & $24.21 \%$ & $29.93 \%$ & $21.15 \%$ & $4.04 \%$ \\
$R W_{1}$ & $9.20 \%$ & $16.55 \%$ & $4.20 \%$ & $3.69 \%$ & $9.03 \%$ & $10.55 \%$ & $7.93 \%$ & $1.12 \%$ \\
$R W_{\mathrm{g}}$ & $1.75 \%$ & $4.86 \%$ & $0.02 \%$ & $1.53 \%$ & $4.03 \%$ & $4.96 \%$ & $3.06 \%$ & $0.77 \%$ \\
\hline
\end{tabular}

Note: $E T$ is the actual evapotranspiration, $\mathrm{mm} . R W$ is the contribution of soil-ground water storage utilization. $R W_{1}$ is the contribution of soil-ground water storage utilization below $1 \mathrm{~m}$ soil depth. $R W_{g}$ is the contribution of ground water utilization.

\section{Conclusions}

In this study, a long-term soil moisture content and water table depth dataset are used to estimate soil-ground water storage utilization during the crop growing season and its attribution to irrigation of the non-growing season in arid agricultural areas with shallow water table depth; coefficients of soil-ground water storage utilization, ground water utilization and soil-ground water storage utilization below $1 \mathrm{~m}$ soil depth are also analyzed. The contributions of soil-ground water storage utilization, soil-ground water storage utilization below $1 \mathrm{~m}$ soil depth and ground water utilization to actual evapotranspiration are further evaluated. The major conclusions are as follows:

(1) The soil-ground water storage is critical to crop water consumption during the crop growing season, which accounts for over $23.5 \%$ of the actual evapotranspiration. 
(2) More than $30 \%$ of the autumn irrigation water during the non-growing season can be used as soil-ground water utilization in arid areas with shallow water table depth.

(3) Changing the autumn irrigation scheme and the planting structure can significantly impact the soil-ground water storage utilization.

(4) The utilization of soil-ground water storage is mainly from the soil depth above $1 \mathrm{~m}$, which contributes more than $60 \%$ of the soil-ground water storage utilization.

(5) For using the water table fluctuation method to estimate the variation of the soil-ground water storage, one should be careful in choosing the suitable coefficient. The commonly used specific yield obtained by pumping tests would overestimate the ground water utilization and underestimate the soil-ground water utilization.

Author Contributions: Conceptualization, T.Z., Y.Z. and J.Y.; methodology, T.Z., Y.Z. and J.Y.; software, T.Z.; validation, T.Z., Y.Z., and W.M.; formal analysis, T.Z.; investigation, Y.Z., J.W., W.M., and J.Y.; resources, Y.Z. and J.Y.; data curation, Y.Z. and J.Y.; writing—original draft preparation, T.Z.; writing—review and editing, Y.Z., M.Y., and W.M.; visualization, T.Z. and Y.Z.; supervision, Y.Z.; project administration, Y.Z.; funding acquisition, Y.Z. and J.Y. All authors have read and agreed to the published version of the manuscript.

Funding: This research was funded by Natural Science Foundation of China through Grants 51779178, 51790533, and 51629901, the National Key Research and Development Program of China (2017YFC0403301), and the project of water conservancy science and technology plan in Inner Mongolia Autonomous Region (Grant No. 213-03-99-303002-NSK2017-M1).

Conflicts of Interest: The authors declare no conflict of interest.

\section{References}

1. Cai, X.; McKinney, D.C.; Rosegrant, M.W. Sustainability analysis for irrigation water management in the Aral Sea region. Agric. Syst. 2003, 76, 1043-1066. [CrossRef]

2. Hanasaki, N.; Fujimori, S.; Yamamoto, T.; Yoshikawa, S.; Masaki, Y.; Hijioka, Y.; Kanae, S. A Global Water Scarcity Assessment under Shared Socio-Economic Pathways-Part 2: Water Availability and Scarcity. Hydrol. Earth Syst. Sci. 2013, 17, 2393-2413. [CrossRef]

3. Liu, Z.; Chen, H.; Huo, Z.; Wang, F.; Shock, C.C. Analysis of the contribution of groundwater to evapotranspiration in an arid irrigation district with shallow water table. Agric. Water Manag. 2016, 171, 131-141. [CrossRef]

4. Zhang, Y.; Kendy, E.; Qiang, Y.; Changming, L.; Yanjun, S.; Hongyong, S. Effect of soil water deficit on evapotranspiration, crop yield, and water use efficiency in the North China Plain. Agric. Water Manag. 2004, 64, 107-122. [CrossRef]

5. Lam, A.; Karssenberg, D.; van den Hurk, B.J.J.M.; Bierkens, M.F.P. Spatial and temporal connections in groundwater contribution to evaporation. Hydrol. Earth Syst. Sci. 2011, 15, 2621-2630. [CrossRef]

6. Li, R.; Shi, H.; Flerchinger, G.N.; Akae, T.; Wang, C. Simulation of freezing and thawing soils in Inner Mongolia Hetao Irrigation District, China. Geoderma 2012, 173, 28-33. [CrossRef]

7. Li, R.; Shi, H.; Flerchinger, G.N.; Zou, C.; Li, Z. Modeling the effect of antecedent soil water storage on water and heat status in seasonally freezing and thawing agricultural soils. Geoderma 2013, 206, 70-74. [CrossRef]

8. Lu, X.; Li, R.; Shi, H.; Liang, J.; Miao, Q.; Fan, L. Successive simulations of soil water-heat-salt transport in one whole year of agriculture after different mulching treatments and autumn irrigation. Geoderma 2019, 344, 99-107. [CrossRef]

9. Xu, X.; Huang, G.; Qu, Z.; Pereira, L.S. Assessing the groundwater dynamics and impacts of water saving in the Hetao Irrigation District, Yellow River basin. Agric. Water Manag. 2010, 98, 301-313. [CrossRef]

10. Han, Y. Autumn Irrigation Schedule in Hetao Irrigation District Based on SWAP-SHAW Coupling Model. Master's Thesis, Tsinghua University, Beijing, China., 2017. (In Chinese).

11. Loheide, S.P.; Butler, J.J.; Gorelick, S.M. Estimation of groundwater consumption by phreatophytes using diurnal water table fluctuations: A saturated-unsaturated flow assessment. Water Resour. Res. 2005, 41, W07030.1-W07030.14. [CrossRef]

12. Nosetto, M.D.; Jobbágy, E.G.; Jackson, R.B.; Sznaider, G.A. Reciprocal influence of crops and shallow ground water in sandy landscapes of the Inland Pampas. Field Crop. Res. 2009, 113, 138-148. [CrossRef] 
13. Yeh, P.J.; Famiglietti, J.S. Regional Groundwater Evapotranspiration in Illinois. J. Hydrometeorol. 2009, 10, 464-478. [CrossRef]

14. Yang, J.; Li, B.; Liu, S.P. A large weighing lysimeter for evapotranspiration and soil-water-groundwater exchange studies. Hydrol. Process. 2000, 14, 1887-1897. [CrossRef]

15. Wu, Y.; Liu, T.; Paredes, P.; Duan, L.; Pereira, L.S. Water use by a groundwater dependent maize in a semi-arid region of Inner Mongolia: Evapotranspiration partitioning and capillary rise. Agric. Water Manag. 2015, 152, 222-232. [CrossRef]

16. Luo, Y.; Sophocleous, M. Seasonal groundwater contribution to crop-water use assessed with lysimeter observations and model simulations. J. Hydrol. 2010, 389, 325-335. [CrossRef]

17. Bandyopadhyay, P.K.; Mallick, S. Actual evapotranspiration and crop coefficients of wheat (Triticum aestivum) under varying moisture levels of humid tropical canal command area. Agric. Water Manag. 2003, 59, $33-47$. [CrossRef]

18. Luo, Y.; He, C.; Sophocleous, M.; Yin, Z.; Hongrui, R.; Ouyang, Z. Assessment of crop growth and soil water modules in SWAT2000 using extensive field experiment data in an irrigation district of the Yellow River Basin. J. Hydrol. 2008, 352, 139-156. [CrossRef]

19. Zhang, Y.; Wegehenkel, M. Integration of MODIS data into a simple model for the spatial distributed simulation of soil water content and evapotranspiration. Remote Sens. Environ. 2006, 104, 393-408. [CrossRef]

20. Soppe, R.W.O.; Ayars, J.E. Characterizing ground water use by safflower using weighing lysimeters. Agric. Water Manag. 2003, 60, 59-71. [CrossRef]

21. Soylu, M.E.; Istanbulluoglu, E.; Lenters, J.D.; Wang, T. Quantifying the impact of groundwater depth on evapotranspiration in a semi-arid grassland region. Hydrol. Earth Syst. Sci. 2011, 15, 787-806. [CrossRef]

22. Robock, A.; Vinnikov, K.Y.; Srinivasan, G.; Entin, J.K.; Hollinger, S.E.; Speranskaya, N.A.; Namkhai, A. The Global Soil Moisture Data Bank. Bull. Amer. Meteorol. Soc. 2000, 81, 1281-1299. [CrossRef]

23. Wang, Y.; Shao, M.; Liu, Z. Vertical distribution and influencing factors of soil water content within 21-m profile on the Chinese Loess Plateau. Geoderma 2013, 193, 300-310. [CrossRef]

24. Qu, Z.; Liu, T.; Kang, Y.; Huang, Y. The Analysis of Different Scales Diversity Law of Irrigation Water Efficiency and Water Saving Potential in Yellow River Irrigation Areas of Inner Mongolia; Science Press: Beijing, China, 2018. (In Chinese)

25. Yang, Y.; Shang, S.; Jiang, L. Remote Sensing Temporal and Spatial Patterns of Evapotranspiration and the Responses to Water Management in a Large Irrigation District of North China. Agric. For. Meteorol. 2012, 164, 112-122. [CrossRef]

26. Yu, B.; Shang, S.; Zhu, W.; Gentine, P.; Cheng, Y. Mapping daily evapotranspiration over a large irrigation district from MODIS data using a novel hybrid dual-source coupling model. Agric. For. Meteorol. 2019, 276, 107612. [CrossRef]

27. Yang, J.; Wan, S.; Deng, W.; Zhang, G. Water fluxes at a fluctuating water table and groundwater contributions to wheat water use in the lower Yellow River flood plain, China. Hydrol. Process. 2007, 21, 717-724. [CrossRef]

28. Doble, R.C.; Crosbie, R.S. Review: Current and emerging methods for catchment-scale modelling of recharge and evapotranspiration from shallow groundwater. Hydrogeol. J. 2017, 25, 3-23. [CrossRef]

29. Peng, Z.; Zhang, B.; Cai, J.; Wei, Z.; Chen, H.; Liu, Y. Optimization of Spring Wheat Irrigation Schedule in Shallow Groundwater Area of Jiefangzha Region in Hetao Irrigation District. Water 2019, 11, 2627. [CrossRef]

30. Forkutsa, I.; Sommer, R.; Shirokova, Y.I.; Lamers, J.P.A.; Kienzler, K.; Tischbein, B.; Vlek, P.L.G. Modeling irrigated cotton with shallow groundwater in the Aral Sea Basin of Uzbekistan: I. Water dynamics. Irrig. Sci. 2009, 27, 331-346. [CrossRef]

31. Chen, H.; Liu, Z.; Huo, Z.; Qu, Z.; Xia, Y.; Fernald, A. Impacts of agricultural water saving practice on regional groundwater and water consumption in an arid region with shallow groundwater. Environ. Earth Sci. 2016, 75, 1204. [CrossRef]

32. Ren, D.; Xu, X.; Huang, G. Irrigation water use in typical irrigation and drainage system of Hetao Irrigation District. Trans. Chin. Soc. Agric. Eng. 2019, 35, 98-105. (In Chinese) [CrossRef]

33. Raghavendra, N.S.; Deka, P.C. Support vector machine applications in the field of hydrology: A review. Appl. Soft. Comput. 2014, 19, 372-386. [CrossRef]

34. Cheng, D.; Wang, W.; Zhan, H.; Zhang, Z.; Chen, L. Quantification of transient specific yield considering unsaturated-saturated flow. J. Hydrol. 2020, 580, 124043. [CrossRef] 
35. Freeze, R.A.; Cherry, J.A. Groundwater; Prentice-Hall: Upper Saddle River, NJ, USA, 1979; 604p, ISBN 0-13-365312-9.

36. Moench, A.F. Specific yield as determined by type-curve analysis of aquifer-test data. Groundwater 1994, 32, 949-958. [CrossRef]

37. Nwankwor, G.I.; Cherry, J.A.; Gillham, R.W. A Comparative Study of Specific Yield Determinations for a Shallow Sand Aquifer. Groundwater 1984, 22, 764-772. [CrossRef]

38. Malama, B. Alternative linearization of water table kinematic condition for unconfined aquifer pumping test modeling and its implications for specific yield estimates. J. Hydrol. 2011, 399, 141-147. [CrossRef]

39. Neuman, S.P. Theory of flow in unconfined aquifers considering delayed response of the water table. Water Resour. Res. 1972, 8, 1031-1045. [CrossRef]

40. Gao, X.; Huo, Z.; Bai, Y.; Feng, S.; Huang, G.; Shi, H.; Qu, Z. Soil salt and groundwater change in flood irrigation field and uncultivated land: A case study based on 4-year field observations. Environ. Earth Sci. 2015, 73, 2127-2139. [CrossRef]

41. Chen, H.; Huo, Z.; Dai, X.; Ma, S.; Xu, X.; Huang, G. Impact of agricultural water-saving practices on regional evapotranspiration: The role of groundwater in sustainable agriculture in arid and semi-arid areas. Agric. Meteorol. 2018, 263, 156-168. [CrossRef]

42. Li, Y.; Wu, C.; Bao, M.; Gu, X. Research on the Spacing of Regional Meteorological Stations in Hulun Buir Grassland. In Proceedings of the 32nd annual meeting of Chinese Meteorological Society, Tianjing, China, 14 October 2015; Chinese Meteorological Society: Beijing, China, 2015. (In Chinese).

43. Ren, D.; Xu, X.; Hao, Y.; Huang, G. Modeling and assessing field irrigation water use in a canal system of Hetao, upper Yellow River basin: Application to maize, sunflower and watermelon. J. Hydrol. 2016, 532, 122-139. [CrossRef]

44. Mogheir, Y.; de Lima, J.L.M.P.; Singh, V.P. Characterizing the spatial variability of groundwater quality using the entropy theory: I. Synthetic data. Hydrol. Process. 2004, 18, 2165-2179. [CrossRef]

45. Wu, C.L.; Chau, K.W.; Li, Y.S. Methods to improve neural network performance in daily flows prediction. J. Hydrol. 2009, 372, 80-93. [CrossRef]

46. Evett, S.R.; Kustas, W.P.; Gowda, P.H.; Anderson, M.C.; Prueger, J.H.; Howell, T.A. Overview of the Bushland Evapotranspiration and Agricultural Remote sensing EXperiment 2008 (BEAREX08): A field experiment evaluating methods for quantifying ET at multiple scales. Adv. Water Resour. 2012, 50, 4-19. [CrossRef]

47. Abdi, H. Coefficient of variation. In Encyclopedia of Research Design, 1st ed.; Salkind, N., Ed.; Sage: Thousand Oaks, CA, USA, 2010; Volume 1, pp. 169-171. [CrossRef]

48. Xi, H.; Feng, Q.; Si, J.; Chang, Z.; Cao, S. Impacts of river recharge on groundwater level and hydrochemistry in the lower reaches of Heihe River Watershed, northwestern China. Hydrogeol. J. 2010, 18, 791-801. [CrossRef]

49. Huang, T.; Pang, Z. Changes in groundwater induced by water diversion in the Lower Tarim River, Xinjiang Uygur, NW China: Evidence from environmental isotopes and water chemistry. J. Hydrometeorol. 2010, 387, 188-201. [CrossRef]

50. Yue, W.; Liu, X.; Wang, T.; Chen, X. Impacts of water saving on groundwater balance in a large-scale arid irrigation district, northwest china. Irrig. Sci. 2016, 34, 297-312. [CrossRef]

51. Steinwand, A.L.; Harrington, R.F.; Or, D. Water balance for Great Basin phreatophytes derived from eddy covariance, soil water, and water table measurements. J. Hydrol. 2006, 329, 595-605. [CrossRef]

52. Nwankwor, G.I.; Gillham, R.W.; van der Kamp, G.; Akindunni, F.F. Unsaturated and saturated flow in response to pumping of an unconfined aquifer: Field evidence of delayed drainage. Groundwater 1992, 30, 690-700. [CrossRef]

53. Zhang, R.; Wang, P. A preliminary study on the mechanism of water release from saturated layered soils. J. Wuhan Coll. Geol. 1985, 10, 21-27. (In Chinese)

Publisher's Note: MDPI stays neutral with regard to jurisdictional claims in published maps and institutional affiliations. 